\title{
Epidemiology of lobomycosis-like disease in bottlenose dolphins Tursiops spp. from South America and southern Africa
}

\author{
Marie-Françoise Van Bressem ${ }^{1, *}$, Paulo C. Simões-Lopes ${ }^{2}$, Fernando Félix ${ }^{3}$, \\ Jeremy J. Kiszka ${ }^{4}$, Fabio G. Daura-Jorge ${ }^{2}$, Isabel C. Avila ${ }^{5}$, Eduardo R. Secchi ${ }^{6,7}$, \\ Leonardo Flach ${ }^{8}$, Pedro F. Fruet ${ }^{6,7}$, Kate du Toit ${ }^{9}$, Paulo H. Ott ${ }^{10,11}$, Simon Elwen ${ }^{9}$, \\ Amanda B. Di Giacomo ${ }^{11}$, Jeanne Wagner ${ }^{12}$, Aaron Banks ${ }^{13}$, Koen Van Waerebeek ${ }^{1}$
}

\footnotetext{
${ }^{1}$ Cetacean Conservation Medicine Group (CMED), Peruvian Centre for Cetacean Research (CEPEC), Museo de Delfines, Pucusana, Peru

${ }^{2}$ Laboratory of Aquatic Mammals, Department of Ecology and Zoology, Federal University of Santa Catarina, PO Box 5102,

${ }^{3}$ Museo de Ballenas, Av. General Enríquez Gallo, entre calles 47 y 50, Salinas, Ecuador

${ }^{4}$ Department of Biological Sciences, Florida International University, 3000 NE 151st Street, North Miami, FL 33181, USA

${ }^{5}$ Department of Biometry and Environmental System Analysis, University of Freiburg, 79106 Freiburg, Germany

${ }^{6}$ Laboratório de Ecologia e Conservação da Megafauna Marinha - EcoMega, Instituto de Oceanografia, Universidade Federal do Rio Grande/FURG, Cx.P. 474 Rio Grande, RS 96203-900, Brazil

${ }^{7}$ Museu Oceanográfico ‘Prof. Eliézer de C. Rios'/FURG, Rua Heitor Perdigão 10, Rio Grande, RS 96200-970, Brazil

${ }^{8}$ Instituto Boto Cinza, Itacuruçá, Mangaratiba, RJ 23860-000, Brazil

${ }^{9}$ Mammal Research Institute, Department of Zoology and Entomology, University of Pretoria, Pretoria 0002, South Africa

${ }^{10}$ Universidade Estadual do Rio Grande do Sul (Uergs),

Laboratório de Ecologia e Conservação de Organismos e Ambientes Aquáticos (ECOAqua), Rua Machado de Assis, 1456, Osório, RS 95520-000, Brazil

${ }^{11}$ Grupo de Estudos de Mamíferos Aquáticos do Rio Grande do Sul (GEMARS), Rua Machado de Assis, 1456, Osório, RS 95520-000, Brazil

${ }^{12}$ Laboratoire ECOMAR, Université de la Réunion, 15 avenue René Cassin, BP 7151, 97715 St Denis Cedex, la Réunion, France

${ }^{13}$ Centre for Dolphin Studies, PO Box 1856, Plettenberg Bay, South Africa
}

\begin{abstract}
We report on the epidemiology of lobomycosis-like disease (LLD), a cutaneous disorder evoking lobomycosis, in 658 common bottlenose dolphins Tursiops truncatus from South America and 94 Indo-Pacific bottlenose dolphins T. aduncus from southern Africa. Photographs and stranding records of 387 inshore residents, 60 inshore non-residents and 305 specimens of undetermined origin (inshore and offshore) were examined for the presence of LLD lesions from 2004 to 2015. Seventeen residents, 3 non-residents and 1 inshore dolphin of unknown residence status were positive. LLD lesions appeared as single or multiple, light grey to whitish nodules and plaques that may ulcerate and increase in size over time. Among resident dolphins, prevalence varied significantly among 4 communities, being low in Posorja $(2.35 \%, \mathrm{n}=85)$, Ecuador, and high in Salinas, Ecuador $(16.7 \%, \mathrm{n}=18)$, and Laguna, Brazil $(14.3 \%, \mathrm{n}=42)$. LLD prevalence increased in 36 T. truncatus from Laguna from $5.6 \%$ in $2007-2009$ to $13.9 \%$ in 2013-2014, albeit not significantly. The disease has persisted for years in dolphins from Mayotte, Laguna, Salinas, the Sanquianga National Park and Bahía Málaga (Colombia) but vanished from the Tramandaí Estuary and the Mampituba River (Brazil). The geographical range of LLD has expanded in Brazil, South Africa and Ecuador, in areas that have been regularly surveyed for 10 to $35 \mathrm{yr}$. Two of the $21 \mathrm{LLD}$-affected dolphins were found dead with extensive lesions in southern Brazil, and 2 others disappeared, and presumably died, in Ecuador. These observations stress the need for targeted epidemiological, histological and molecular studies of LLD in dolphins, especially in the Southern Hemisphere.
\end{abstract}

KEY WORDS: Delphinidae · Cutaneous diseases · Southern Hemisphere - Lacazia loboi · Paracoccidioides spp. 


\section{INTRODUCTION}

Lobomycosis in Delphinidae is a chronic fungal skin infection characterized by greyish, whitish to slightly pink, verrucous lesions, often in pronounced relief, that may ulcerate and form plaques exceeding $30 \mathrm{~cm}$ in their broadest dimension (Caldwell et al. 1975, Simões-Lopes et al. 1993, Reif et al. 2006, Van Bressem et al. 2007). The disease has been observed in common bottlenose dolphins Tursiops truncatus from the USA, Brazil and Europe, in Guiana dolphins Sotalia guianensis from Surinam and in an Indian Ocean humpback dolphin Sousa plumbea from South Africa (Table 1; Caldwell et al. 1975, Symmers 1983, Cowan 1993, Simões-Lopes et al. 1993, Reif et al. 2006, Van Bressem et al. 2007, Rotstein et al. 2009, Lane et al. 2014). Microscopically, lemon-shaped, budding yeast-like organisms resembling Lacazia loboi (Taborda et al. 1999) were detected in skin lesions sampled in T. truncatus (Caldwell et al. 1975, Simões-Lopes et al. 1993, Paniz-Mondolfi et al. 2012, Van Bressem et al. 2007) and a S. guianensis from the Americas (Symmers 1983), and in a $S$. plumbea from South Africa (Lane et al. 2014; Table 1). However, recent molecular characterization of the $43 \mathrm{kDa}$ glycoprotein coding gene and of ribosomal DNA from lesions sampled in $T$. truncatus from the USA and Cuba, and in Indo-Pacific bottlenose dolphins T. aduncus from Japan, indicated that the yeast-like organism infecting these dolphins is more closely related (94-97\%) to Paracoccidioides brasiliensis than to $L$. loboi (Rotstein et al. 2009, Esperón et al. 2012, Ueda et al. 2013). Paracoccidioides spp. and L. loboi are dimorphic fungi that belong to the order Onygenales, family Ajellomycetaceae (Herr et al. 2001, Theodoro et al. 2012). Paracoccidioides spp. are the agents of paracoccidioidomycosis, a serious systemic disease that involves multiple organs including the skin, in humans and terrestrial mammals from South America (Bagagli et al. 2003, Ricci et al. 2004, Corredor et al. 2005, Richini-Pereira et al. 2008, Bocca et al. 2013).

Skin diseases highly reminiscent of lobomycosis but for which a histological diagnosis was not available have been observed in several populations of T. truncatus, T. aduncus, S. guianensis and Australian snubfin dolphin Orcaella heinsohni worldwide and have been called lobomycosis-like disease or lacaziosis-like disease (LLD; based on the name of the fungus L. loboi, which was initially believed to cause lobomycosis in dolphins, see Table 1; Van Bressem et al. 2007, 2009a,b, Moreno et al. 2008, Bermúdez et al. 2009, Kiszka et al. 2009, Burdett Hart et al. 2011, Daura-Jorge \& Simões-Lopes 2011, Bessesen et al. 2014, Palmer \& Peterson 2014). In South America, LLD occurs in Brazil, Venezuela, Colombia, Ecuador and Peru with variable prevalence levels (Table 1; Van Bressem et al. 2007, Bermúdez et al. 2009, Daura-Jorge \& Simões-Lopes 2011). This skin condition may progress over time and cover extensive body areas, but it is not known to regress (Kiszka et al. 2009, Daura-Jorge \& Simões-Lopes 2011, Bessesen et al. 2014). LLD has been associated with the death or disappearance of severely affected individuals, including calves (Simões-Lopes et al. 1993, Van Bressem et al. 2007, Moreno et al. 2008, Kiszka et al. 2009, Daura-Jorge \& Simões-Lopes 2011).

Over the past $10 \mathrm{yr}$, we have observed new cases of LLD in bottlenose dolphins from South America and southern Africa, sometimes in areas where the disease had never been seen before although they had been surveyed for several years. As earlier recommendations urged close follow-up work on the dynamics and spread of skin diseases worldwide (IWC 2009), here we report on these cases as well as on the progression of the lesions in some individuals, and on the geographic expansion of the disease in Brazil, Ecuador and southern Africa.

\section{MATERIALS AND METHODS}

\section{Study areas and surveys}

Photo-identification (PI) surveys, most of these dedicated and spanning multiple years, were carried out in South Africa, Mayotte, Ecuador, Colombia and Brazil between 2004 and 2015. Some surveys were opportunistic and were implemented during whalewatching activities, acoustic research or shark studies. Systematic beach combing to record and sample stranded marine mammals was also carried out in southern Brazil in 2004 to 2014. The areas studied included bays, lagoons, estuaries and coastal waters for which salinity, water quality and sea surface temperatures (SST) varied widely (Table 2). We provide mid-point coordinates for the marine parks, bays, lagoons and estuaries and the northern and southern limits for the areas covered during beach surveys.

\section{Mayotte}

Located in the northern Mozambique Channel, Mayotte $\left(12^{\circ} 50^{\prime} \mathrm{S}, 45^{\circ} 10^{\prime} \mathrm{E}\right)$ is almost entirely surrounded by a $197 \mathrm{~km}$ long barrier reef. The inner 
lagoon ranks as one of the largest in the world (1100 km², Quod et al. 2000) and is home to a resident population of Tursiops aduncus estimated at $82 \pm 19$ individuals (Kiszka et al. 2012, Pusineri et al. 2014). The human population has been growing quickly in Mayotte during the last $30 \mathrm{yr}$, and urbanization as well as agriculture have been increasing steadily together with the release of untreated freshwater run-off in the lagoon. Contamination by immunosuppressive polychlorinated biphenyls has increased in hooded oysters Saccostrea cucullata in the period 1997 to 2007 (Thomassin et al. 2008). From July to October 2014, small-boat based surveys were conducted in the lagoon with sea conditions not exceeding Beaufort 3. Photographs were taken with a digital $35 \mathrm{~mm}$ camera equipped with a $100-300 \mathrm{~mm}$ lens (Kiszka et al. 2009, 2012). Data were collected during 35 survey days, resulting in 29 encounters with $T$. aduncus. A total of 250 photographs allowed us to identify 16 new individuals and to recapture 19 dolphins identified during studies carried out from 2004 to 2009 (Kiszka et al. 2012, Pusineri et al. 2014).

\section{South Africa}

Located in the Western Cape Province, Plettenberg Bay $\left(34^{\circ} 02^{\prime} \mathrm{S}, 23^{\circ} 22^{\prime} \mathrm{E}\right)$ is separated from the Indian Ocean by the Robberg Peninsula. It receives freshwaters from the Keurbooms and Piesangs Rivers, considered of good quality with only some human-related disturbance (Department of Water Affairs, South Africa: www.dwa.gov.za/iwqs/rhp/state_of_rivers.html). The T. aduncus sub-population inhabiting Plettenberg Bay was estimated to number between 1099 and 9492 individuals (95\% CI, Phillips 2006). It is part of a larger population of over 16000 individuals that ranges along the South African coastline (Reisinger \& Karczmarski 2010). Data were available for 203 days in the period 2007 to 2010 from a variety of sources, mainly collected off tour vessels by research interns with a smaller proportion (10 days) taken from dedicated T. aduncus focussed surveys in 2009 (T. Gridley pers. comm). Some 165 images of 59 dolphins were of sufficient quality to identify skin diseases on the body areas visible when surfacing.

\section{Ecuador}

Posorja $\left(02^{\circ} 42^{\prime} \mathrm{S}, 80^{\circ} 15^{\prime} \mathrm{W}\right)$, a small village in Guayas Province at the Guayas River delta, is home to a resident $T$. truncatus community estimated at about 100 individuals, of which 85 have been photoidentified (F. Félix unpublished data). Its fluviatile influenced coastal waters are contaminated by wastewater from fish-processing industries, shrimp farms and from Guayaquil, Ecuador's largest city. In addition, run-off waters containing pesticides and other agrochemicals used in banana and rice plantations in the lower basin of the Guayas River are discharged by several rivers into the inner estuary (CPPS 2014). Thirty-three dedicated PI surveys on 8-10 m boats were conducted in Posorja in 2005 to 2014 using digital cameras (6-18 megapixels) with 70-300 and $100-400 \mathrm{~mm}$ zooms. In total, 4270 images of regular to good quality were analysed for this study.

Located in the south-eastern part of the inner estuary of the Gulf of Guayaquil, Bajo Alto $\left(03^{\circ} 03^{\prime} \mathrm{S}\right.$, $79^{\circ} 53^{\prime} \mathrm{W}$ ) was surveyed on 14 April 2013. Among a large group of $T$. truncatus, 42 individuals were identified. These dolphins belong to another community separate from the one residing in the inner estuary affected by LLD in 1990-1991 (Félix 1997, Van Bressem et al. 2007, F. Félix unpublished data). Although most habitat and environmental parameters are similar to those of Posorja, Bajo Alto sees less boat traffic and a more extensive use of fishing nets.

Located at the northern edge of the Gulf of Guayaquil, Salinas $\left(02^{\circ} 20^{\prime} \mathrm{S}, 81^{\circ} 00^{\prime} \mathrm{W}\right)$ in Santa Elena Province features a major yacht marina, a large artisanal fisheries port and a port for oil tankers, leading to heavy maritime traffic. It is also the main tourist site on the south-west coast of Ecuador. The adjacent coast boasts a string of densely populated seaside resorts and is affected by high levels of microbiological and chemical pollution (Hurtado et al. 2012). A small resident community of $T$. truncatus is frequently observed close to the port of Salinas. Opportunistic surveys were carried out in 2006 to 2014 during whale watching trips in the summer months (June to October). A total of 502 images, from regular to good quality, were available for skin disease assessment.

\section{Colombia}

Declared a National Natural Park in 2010, Bahía Málaga $\left(3^{\circ} 56^{\prime} \mathrm{N}, 77^{\circ} 21^{\prime} \mathrm{W}\right)$, Valle del Cauca, lies $36 \mathrm{~km}$ north of the port of Buenaventura in the Pacific Ocean. It is home to a likely resident $T$. truncatus community (Rengifo et al. 1995) where 2 cases of LLD were observed in 2005 to 2006 (Van Bressem et al. 2007, Table 1). The bay is chemically contaminated by illegal logging, by heavy metals from the mining industry in the Dagua and San Juan Rivers and by oil 


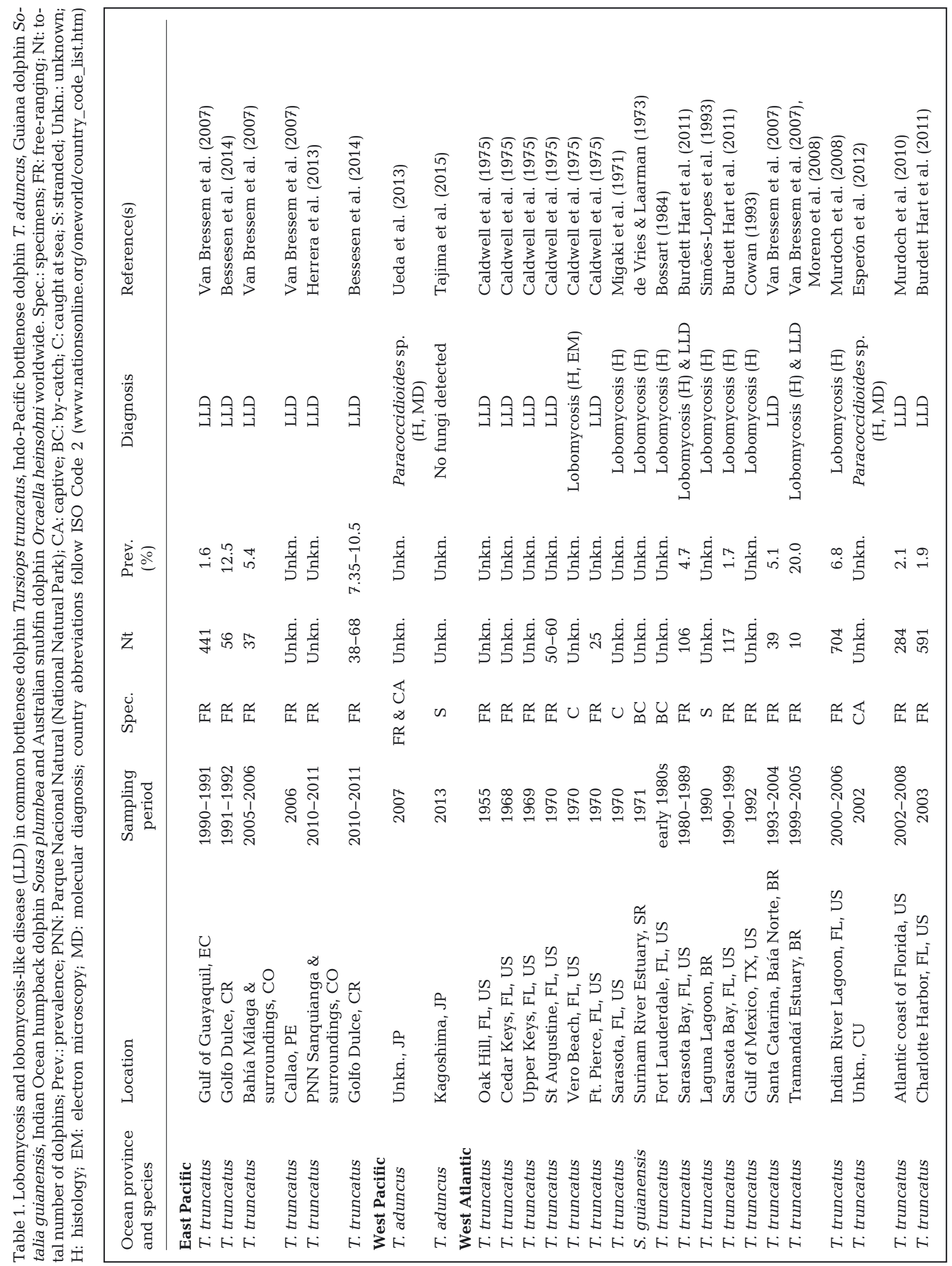




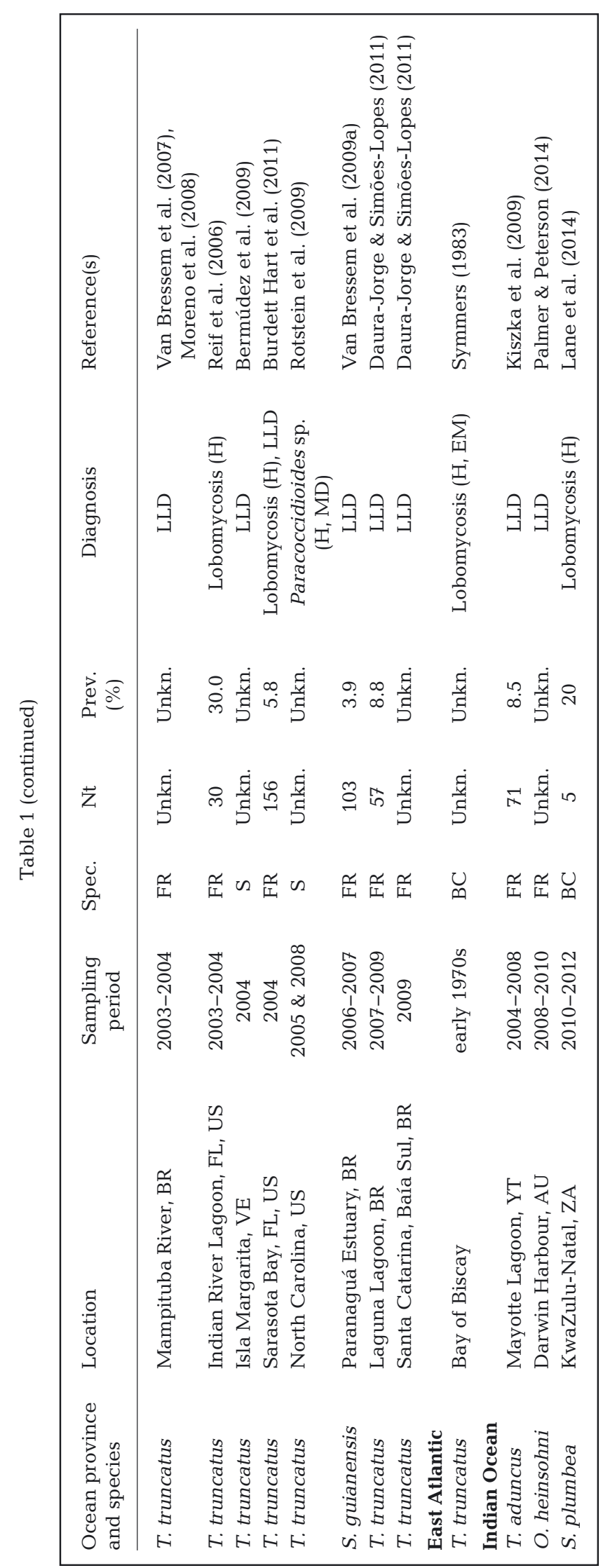

pollution (Torres et al. 2012, PNN Uramba Bahía Málaga 2014). Dedicated surveys were conducted daily from a $20 \mathrm{~m}$ high shore platform using $7 \times 50$ binoculars in August and September 2008. Effort time was $488 \mathrm{~h}$ of observation.

Located in the Nariño department, bordering Ecuador, the Sanquianga National Park $\left(02^{\circ} 55^{\prime} \mathrm{N}\right.$, $78^{\circ} 30^{\prime} \mathrm{W}$ ) covers $8900 \mathrm{~km}^{2}$ along a $60 \mathrm{~km}$ coastal strip of Colombia's Pacific Ocean (Naranjo et al. 2006). Comprising a large delta formed by the Sanquianga, Patía, La Tola, Aguacatal and Tapaje Rivers, the park protects a complex system of estuaries, channels, open lagoons and intertidal sand plains, mostly covered by dense mangrove forest (Díaz \& Acero 2003). The coastal waters adjacent to the park are home to a community of $T$. truncatus that is seen year-round and is likely resident. Two cases of LLD were observed in this community in 2010 to 2011 (Table 1; Herrera et al. 2013). The rivers, especially the Patía, are biologically and chemically contaminated by fertilizers used for coca plantations, by heavy metals from the mining industry, by the inadequate management of solid waste from local people and by commercial logging (PNN Sanquianga 2013, Parra \& Restrepo 2014). PI surveys (29 h) were conducted opportunistically from a fibreglass boat in the waters adjacent to the park from 1 to 6 July 2013. Thirteen images of regular quality were used for skin disease assessment.

\section{Brazil}

In the period 2005 to 2015 , weekly boat-based surveys were conducted in the Patos Lagoon estuary (PLE; $32^{\circ} 06^{\prime} \mathrm{S}, 52^{\circ} 05^{\prime} \mathrm{W}$ ) and adjacent coastal areas $\left(32^{\circ} 48^{\prime} \mathrm{S}, 52^{\circ} 28^{\prime} \mathrm{W}\right)$ to photo-identify $T$. truncatus, as described by Fruet et al. (2015a,b). Analysis of 80514 photographs taken during 334 boat surveys resulted in the identification of $273 \mathrm{~T}$. truncatus, of which 152 were residents of the PLE and surrounding areas (Fruet et al. 2011, 2015a) and 121 were inshore dolphins that included transient, temporary and partially resident dolphins (R. Genoves pers. comm). During regular beach surveys covering about $345 \mathrm{~km}$ (135 km north to $220 \mathrm{~km}$ south of PLE, $33^{\circ} 44^{\prime} \mathrm{S}$, $53^{\circ} 22^{\prime} \mathrm{W}$ to $31^{\circ} 21^{\prime} \mathrm{S}, 51^{\circ} 01^{\prime} \mathrm{W}$ ) in 2004 to 2014 , $130 \mathrm{~T}$. truncatus were found stranded. Although they mostly included inshore dolphins (residents and nonresidents), a small proportion $(<5 \%)$ may have been offshore T. truncatus (EcoMega unpublished data). The PLE, which covers ca. $971 \mathrm{~km}^{2}$, is connected to the Atlantic Ocean through a single $700 \mathrm{~m}$ wide arti- 


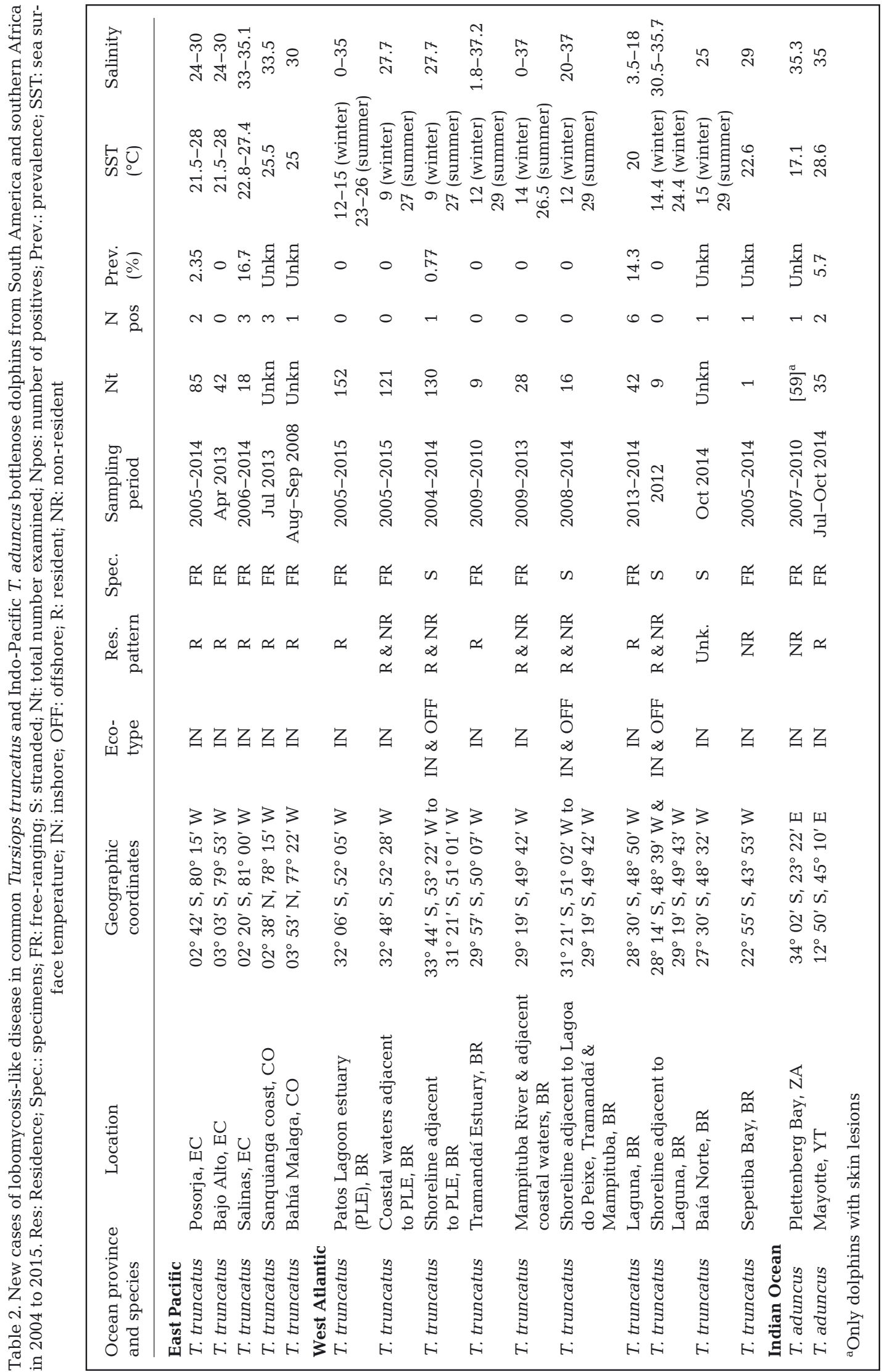


ficial inlet (Kjervfe 1986). The PLE and adjacent areas are characterized by a high anthropogenic influence, including boat traffic, fishing and contamination with polycyclic aromatic hydrocarbons (Garcia et al. 2010) and mercury (Mirlean et al. 2003). The PLE hydrodynamics are mainly driven by wind and freshwater input that result in flood regimes in the channel area and play a key role in the control of salinity (Pinotti et al. 2011).

Located in the north of Rio Grande do Sul, the Tramandaí Lagoon $\left(29^{\circ} 57^{\prime} \mathrm{S}, 50^{\circ} 07^{\prime} \mathrm{W}\right)$ covers an area of about $13 \mathrm{~km}^{2}$ with an average depth of $1.5 \mathrm{~m}$ (Schwarzbold \& Schäfer 1984). It receives fresh water from the Rio Tramandaí and the Camarão Channel and is connected to the Atlantic Ocean by a narrow inlet bordering the municipalities of Imbé and Tramandaí where a small community of $T$. truncatus resides (Simões-Lopes \& Fabian 1999, Zappes et al. 2011, Di Giacomo \& Ott in press). LLD was detected in 2 adults in the period 1999 to 2005 (Moreno et al. 2008). The estuary is contaminated with a high load of faecal coliforms (Haase et al. 2003, FEPAM 2015), hydrocarbons and heavy metals (Andrade et al. 2004, Rocha 2013). During the present study, PI surveys were carried out in the mouth of the Tramandaí estuary in January 2009 to February 2010. About 2050 photographs were analysed, and 9 dolphins were identified, including 3 calves (Di Giacomo \& Ott in press).

The Mampituba River drains a $1200 \mathrm{~km}^{2}$ watershed area, has a mean depth of around $4 \mathrm{~m}$ and is under a microtidal regime ( $\mathrm{D}^{\prime}$ Aquino et al. 2011). The river mouth $\left(29^{\circ} 19^{\prime} \mathrm{S}, 49^{\circ} 42^{\prime} \mathrm{W}\right)$ straddles the border between the states of Rio Grande do Sul and Santa Catarina. Its narrow inlet has been stabilized by jetties to support a fishing harbour since 1970 (Lélis \& Calliari 2006). Along its course, the river receives domestic sewage, agricultural drainage and municipal wastewaters (Andrade et al. 2004). In 1995 to 2008, 6 common bottlenose dolphins had been photoidentified in the river mouth, including 1 with LLD (Moreno et al. 2008). New PI surveys were carried out from April 2009 to April 2013 in the river mouth and adjacent coastal waters, covering $20 \mathrm{~km}$ of the coast. In total, 1480 images were examined and 22 adults were photo-identified. Most of the dolphins were seen in the coastal area outside the estuary, and only 2 entered the channel (Di Giacomo 2014, GEMARS unpublished data), possibly because water quality had deteriorated (Haase et al. 2003, FEPAM 2015). Systematic coastal beach surveys were conducted in 2008 to 2014 to record stranding events along a $260 \mathrm{~km}$ shoreline, ca. $80 \mathrm{~km}$ between the estuaries of Mampituba and Tramandaí and a $180 \mathrm{~km}$ area that extended southward to the Lagoa do Peixe National Park ( $\left.31^{\circ} 21^{\prime} \mathrm{S}, 51^{\circ} 02^{\prime} \mathrm{W}\right)$.

Covering about $300 \mathrm{~km}^{2}\left(28^{\circ} 30^{\prime} \mathrm{S}, 48^{\circ} 50^{\prime} \mathrm{W}\right)$, Laguna is among the largest lagoon systems in southern Brazil consisting of 3 smaller lagoons (Mirim, Imaruí and Santo Antônio). Bordering the city of Laguna, the lagoon is polluted by effluents from anthropogenic activities including rice agriculture, shrimp farming and coal mining (Daura-Jorge \& Simões-Lopes 2011). A community of 52 to 57 resident common bottlenose dolphins, studied since 1989, inhabits the Santo Antônio and Imaruí Lagoons (Simões-Lopes \& Fabian 1999, Daura-Jorge et al. 2013). It is endemically affected by LLD, with a prevalence of $9 \%$ for 57 dolphins in 2007 to 2009 (Daura-Jorge \& Simões-Lopes 2011). During 2013 and 2014, boat surveys were conducted weekly along pre-defined routes to collect photo-identification data (Daura-Jorge et al. 2013). About 12000 photographs were taken during 76 surveys and 42 resident dolphins were identified. In 2012, a coastal beach survey recorded stranding events along $150 \mathrm{~km}$ of shoreline adjacent to Laguna $\left(28^{\circ} 14^{\prime} \mathrm{S}, 48^{\circ} 39^{\prime} \mathrm{W}\right.$ and $\left.29^{\circ} 19^{\prime} \mathrm{S}, 49^{\circ} 43^{\prime} \mathrm{W}\right)$.

Baía Norte $\left(27^{\circ} 30^{\prime} \mathrm{S}, 48^{\circ} 32^{\prime} \mathrm{W}\right)$ and Baía Sul $\left(27^{\circ} 43^{\prime} \mathrm{S}, 48^{\circ} 36^{\prime} \mathrm{W}\right)$ are 2 coastal bays that separate Santa Catarina Island from the mainland. Covering ca. $250 \mathrm{~km}^{2}$, Baía Norte is greatly influenced by open waters. Contiguous to a densely populated area without adequate sanitation, the bay is exposed to high levels of chemical and biological contaminants (Souza et al. 2012). Non-systematic PI surveys in 2008 to 2011 suggest that a small inshore community of at least $11 \mathrm{~T}$. truncatus shows some degree of site fidelity to Baía Norte and/or Baía Sul (F. Daura-Jorge \& P. Simões-Lopes unpubl. data). LLD was reported in 2 T. truncatus from Baía Norte between 1993 and 2004 (Flores et al. 2005, Van Bressem et al. 2007) and in 2 dolphins from Baía Sul in 2009 (Daura-Jorge \& Simões-Lopes 2011).

Located in southern Rio de Janeiro State $\left(22^{\circ} 55^{\prime} \mathrm{S}\right.$, $43^{\circ} 53^{\prime} \mathrm{W}$ ), Sepetiba Bay covers approximately $526 \mathrm{~km}^{2}$ and is connected to the Atlantic Ocean through the western part of the bay. The eastern side features an extensive mangrove forest and receives a high input of fresh water from river drainage systems (Pessanha \& Araújo 2003, Flach et al. 2008). It is home to 4 large ports and suffers from increasing organic and chemical contamination with more than 400 chemical, rubber, printing and metal factories in the surrounding area (Copeland et al. 2003, Molisani et al. 2004, Ribeiro et al. 2013). A resident community of Sotalia guianensis estimated at 1269 dolphins $(95 \% \mathrm{CI}=$ 
739-2196) inhabits the entrance of the bay and has been the object of PI studies since 2005 (Flach et al. 2008). From 2005 to 2014, a total of 334 surveys were conducted along pre-defined routes to collect $S$. guianensis PI data (Flach 2015). T. truncatus were never seen in the bay until September 2013 (Flach 2015).

\section{Data collection and analysis}

The large majority of the bottlenose dolphins examined during this study belong to the inshore ecotype (Table 2). However, an unknown percentage of the dolphins stranded in southern Brazil were likely of the offshore ecotype (Costa et al. 2015, Ott et al. in press). Inshore dolphins were further classified as residents (high sighting frequencies within and between years, high site fidelity) or non-residents (transients and semi-residents; Table 2). Individual dolphins were identified through natural marks (Würsig \& Jefferson 1990). Maturity status (calf, juvenile, adult) was estimated from relative body size and colouration, scars, behavioural clues and from the verified duration of residence (Félix 1994, Di Giacomo \& Ott in press). Calves were defined as individuals whose body length was one-third or less than that of the larger dolphins in the area and which usually remained close to the same adult (Mann \& Smuts 1999, Mann et al. 2000, Fruet et al. 2015a,b).

Holders of PI catalogues of $T$. truncatus and T. aduncus searched for the presence of skin lesions evoking LLD, i.e. multiple firm, light grey or whitish to slightly pink nodules, often raised, forming plaques and ulcerating, which may spread to the entire body (Van Bressem et al. 2007, 2009a, Kiszka et al. 2009, Daura-Jorge \& Simões-Lopes 2011). Images of suspected positive dolphins were extracted and further examined by M.F.V.B. and K.V.W. The relative size of the lesions was expressed as a percentage $(P)=$ $A_{\text {lesion }} / A_{\text {dorsal }} \times 100$, where $A_{\text {lesion }}$ is the area of the lesion and $A_{\text {dorsal }}$ is the 1 -sided area of the dorsal fin (DFA; Daura-Jorge \& Simões-Lopes 2011). Relative size of lesions (\% of DFA) was estimated from images magnified on-screen and assigned to 1 of 4 categories: small $(<10 \%)$, medium $(10-20 \%)$, large (20$50 \%$ ) and very large (>50\%). Time series allowed an evaluation of relative progress in $2 \mathrm{~T}$. truncatus from Posorja and Salinas. Prevalence of LLD was calculated as the ratio of affected individuals to the number of PI dolphins in a community or to the total number of stranded dolphins examined during the study period. In free-ranging dolphins, prevalence levels were minimal as, generally, only the upper body exposed at surfacing could be examined. We only compared communities where dolphins were photo-identified and where LLD was present, which limited our analysis to 4 resident communities (Posorja, Salinas, Laguna and Mayotte). Prevalence variation between study areas was assessed with a Kruskal-Wallis test. Temporal variation in prevalence in Laguna between 2007-2009 and 2014 was examined with McNemar's test using exact binomial probability calculations (www.vassarstats.net/propcorr. html). All significance levels were set at $\alpha=0.05$.

\section{RESULTS}

The presence of LLD was examined in 658 Tursiops truncatus from South America and 94 T. aduncus from southern Africa (Table 2). Photographs and stranding records of 387 inshore residents, 60 inshore nonresidents and 305 specimens of undetermined origin (resident or non-resident inshore or offshore dolphins) were examined for the presence of LLD lesions (Table 2). LLD cases were detected in 17 residents (2, Mayotte; 5, Ecuador; 4, Colombia; 6, Brazil), in 3 nonresidents (1, South Africa; 2, Brazil) and in 1 inshore $T$. truncatus of unknown residence status in Brazil (Fig. 1). The disease had persisted in minimum 3, and perhaps 4, of these dolphins since previous studies (Van Bressem et al. 2007, Kiszka et al. 2009, DauraJorge \& Simões-Lopes 2011). Thus, the number of true new cases amounts to 17 or 18 bottlenose dolphins.

\section{Mayotte}

From July to October 2014, small-boat surveys allowed us to photographically recapture 19 known individuals and to identify an additional $16 \mathrm{~T}$. aduncus. While negative from 2005 to 2008, an adult had developed small and medium LLD lesions on its dorsum and tailstock by October 2014 (Fig. 2A,B). In individual MY08, chronic LLD lesions on the dorsum and tailstock had clearly progressed, covering $1 \%$ of the visible body surface in 2006 (Kiszka et al. 2009) to approximately $20 \%$ in 2014 .

\section{South Africa}

One case of LLD was observed in a T. aduncus in Plettenberg Bay (Fig. 2C) on 11 November 2008. The dolphin had several small to medium-sized nodules, some confluent and ulcerated, on the dorsum, right 
Fig. 1. Locations in South America and Africa where lobomycosis-like disease was observed in bottlenose dolphins Tursiops truncatus and T. aduncus

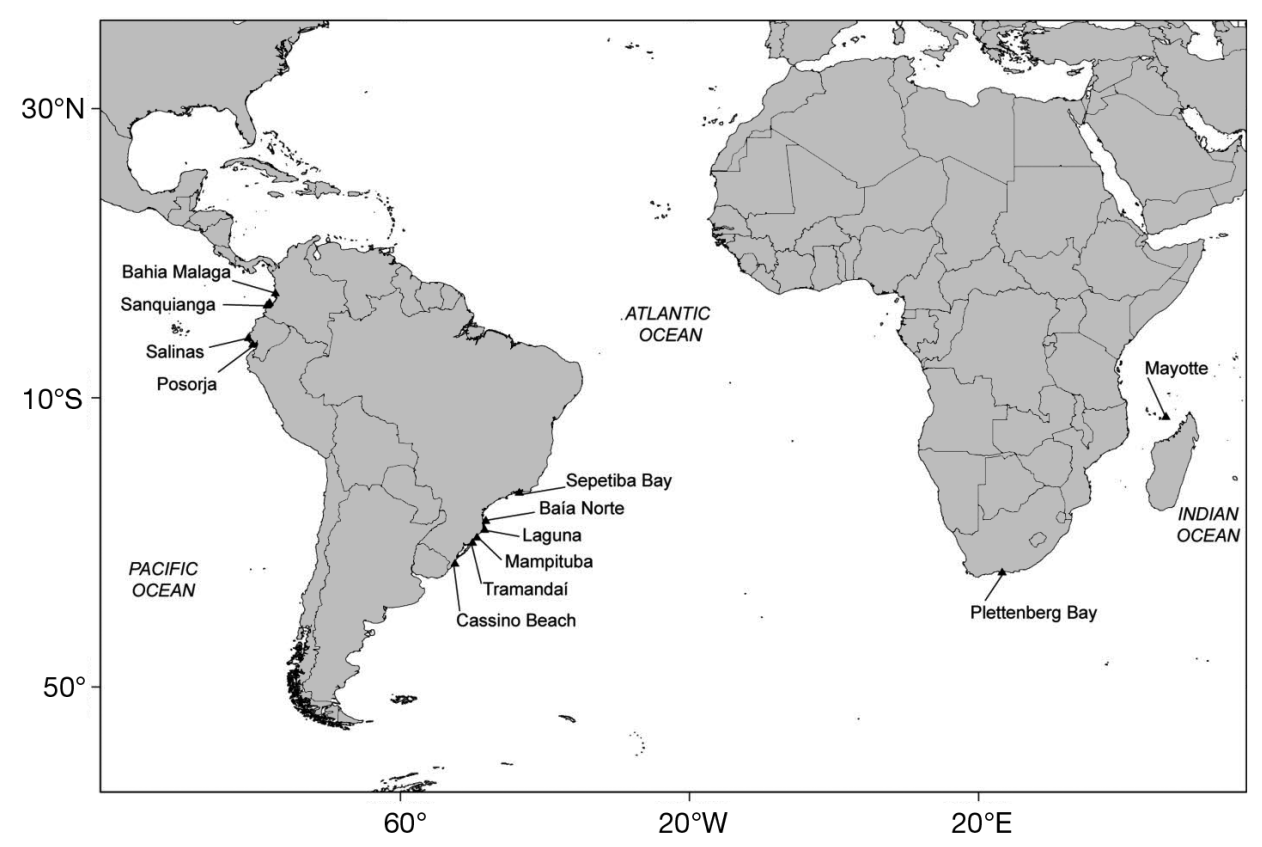

flank (Fig. 2C) and tailstock. LLD was not recognized on any good quality photographs of 58 other individuals identified between 2007 and 2010 and specifically examined for skin disease (du Toit 2011).

\section{Ecuador}

Two (P58 and P59) of 85 (2.35\%) T. truncatus photo-identified since 2005 in Posorja were observed with LLD in April 2011 (Fig. 3A,B). They were seen swimming together on 3 occasions in 2011 but were no longer encountered in 2014. In both individuals, the skin was affected on both sides of the dorsal fin (DF). In P58, small LLD nodules present at the base of the right side of the DF in April 2011 had grown and coalesced to form a larger lesion by February 2013 (Fig. 3A,B), i.e. an increase from 14.5 to $24.4 \%$ of DFA (Fig. 4).

LLD was not detected in $42 \mathrm{~T}$. truncatus photographed in April 2013 in Bajo Alto.

Twenty-one T. truncatus groups (4-8 ind. per group) were observed in Salinas between 2006 and 2014. Of the 18 PI dolphins, $3(16.7 \%)$ showed small to large LLD lesions on the DF, dorsum, flanks and tailstock during that period. In dolphin S4, a whitish lesion located at the base of the dorsal fin (right side) increased markedly from 8.5\% DFA in September 2006 to $28.5 \%$ DFA in April 2010 (Figs. 3C-E \& 4). A lesion located on the left side of the dorsal fin progressed from $25 \%$ DFA in 2006 to $50 \%$ DFA in 2009 (Fig. 4). It did not visibly grow in 2010 to 2011 (Fig. 4).
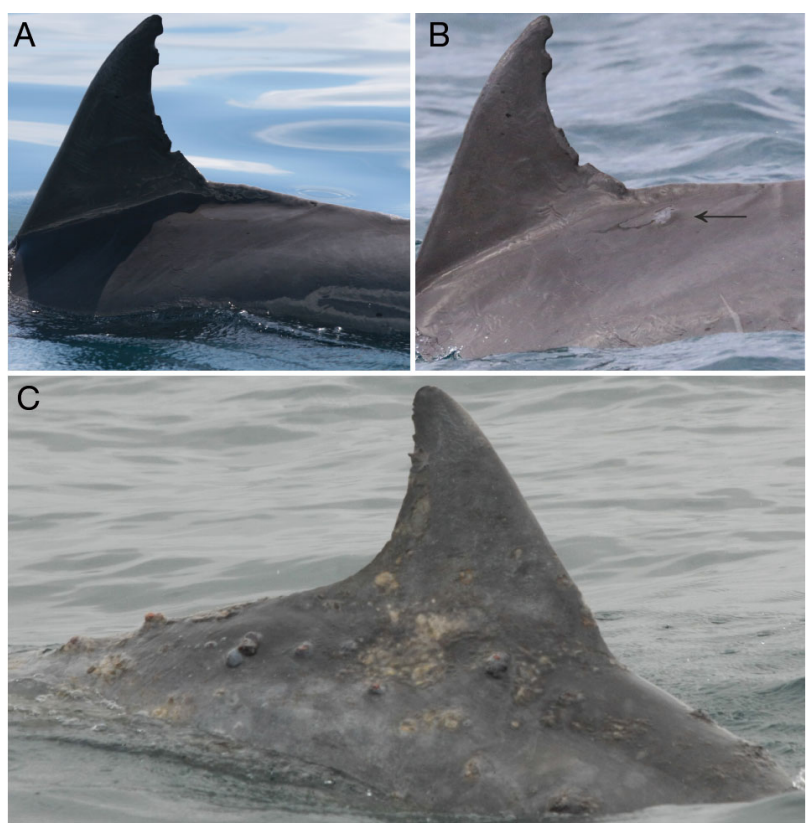

Fig. 2. Lobomycosis-like disease (LLD) in Indo-Pacific bottlenose dolphins Tursiops aduncus from the Indian Ocean. (A) Absence of LLD in a dolphin from Mayotte in 2005; (B) small and medium-sized LLD lesions on the dorsum of the same dolphin in October 2014; (C) several small to mediumsized LLD lesions on the back and right flank of a T. aduncus from Plettenberg Bay, South Africa, in November 2008

\section{Colombia}

An adult T. truncatus with LLD lesions was sighted in Bahía Málaga on 9 August 2008 (Table 2). The dolphin was part of a group of 9 individuals. However, 


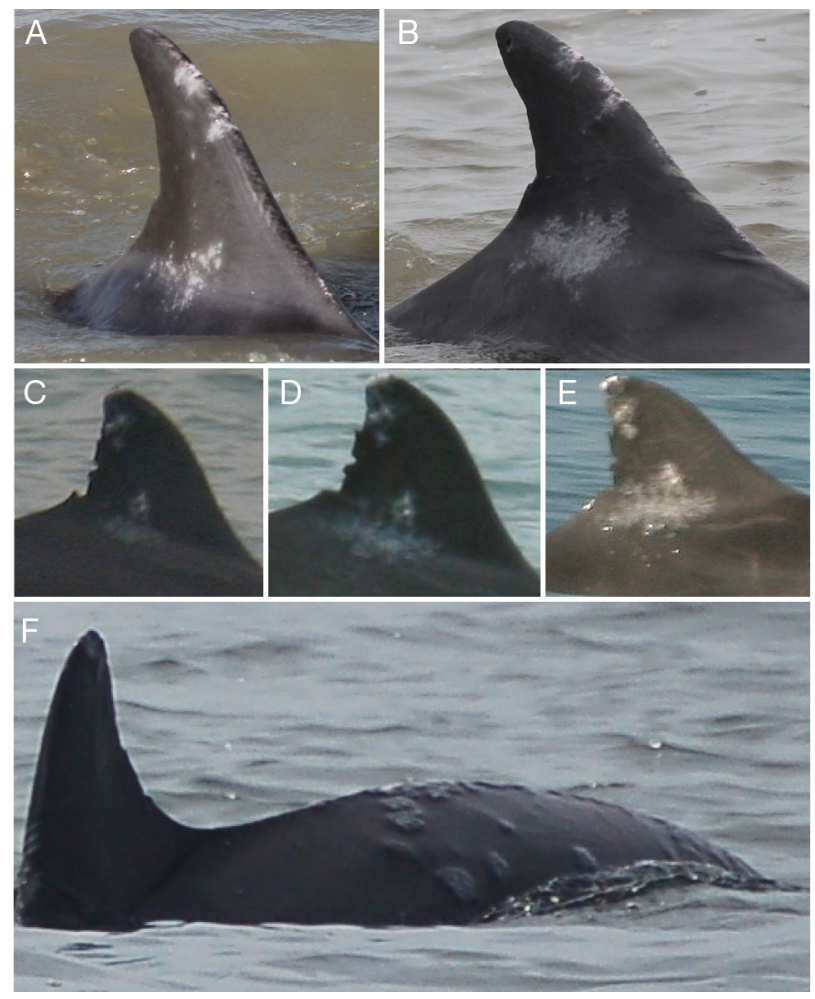

Fig. 3. Lobomycosis-like disease (LLD) in common bottlenose dolphins Tursiops truncatus from the Southeast Pacific. Progression of LLD in dolphin P58 in (A) April 2011 and (B) February 2013 from Posorja, Ecuador; and in individual S4 from the Salinas community (Ecuador) in (C) 2006, (D) 2008 and (E) 2010. (F) LLD lesions on the dorsum and flank of a dolphin nearshore in Sanquianga National Park, Colombia, 3 July 2013

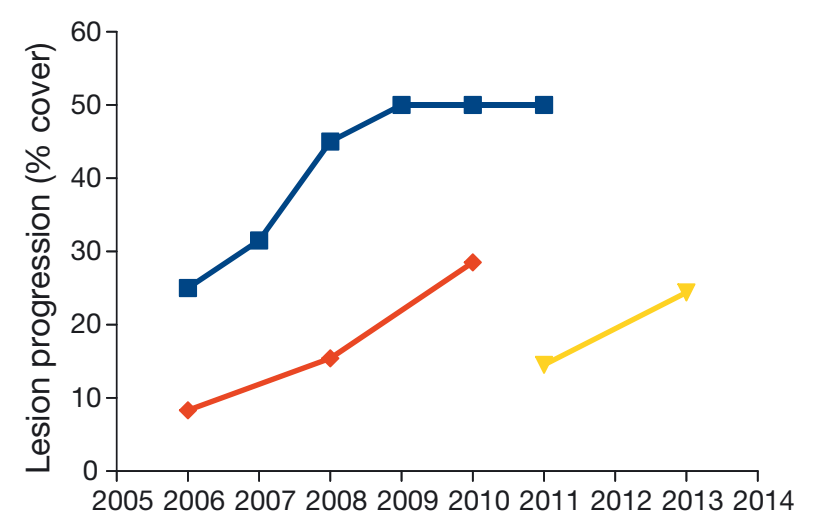

Fig. 4. Progression of some lobomycosis-like disease lesions in bottlenose dolphins Tursiops truncatus $\mathrm{S} 4$ (blue = left side of dorsal fin, red = right side of dorsal fin) and P58 (yellow) from Ecuador

as it was not photo-identified, it is unknown whether it corresponded to 1 of the 2 affected individuals reported in 2005 and 2006 (Van Bressem et al. 2007) or whether it represented a new case.
Small to medium LLD lesions were seen in 2 T. truncatus among a group of 50 passing off 'Playa Mulatos' in Pacific waters adjacent to the Sanquianga National Park on 3 July 2013 (Fig. 3C, Table 2). On 6 July 2013, another T. truncatus with possible LLD lesions was observed among 20 dolphins feeding at the mouth of the Amarales River, close to the village of Amarales, in the park. These dolphins were different from the 3 individuals with LLD documented in 2010 to 2011 by Herrera et al. (2013).

\section{Brazil}

Rio Grande do Sul State

LLD was not detected in 152 PLE T. truncatus from the Patos Lagoon estuary during 10 yr (2005-2015) of systematic PI studies and more than $20 \mathrm{yr}$ of nonsystematic PI studies (EcoMega unpubl. data; Table 2). It was also not detected in 121 resident and nonresident inshore $T$. truncatus inhabiting coastal waters adjacent to the PLE and photo-identified during the same period. Among the $130 \mathrm{~T}$. truncatus of mixed origin found washed ashore during beach surveys along the seashores adjacent to the PLE in 2004 to 2014, 1 dolphin (0.77\%) had LLD (Table 2). The $26 \mathrm{yr}$ old male stranded dead at Cassino Beach $\left(32^{\circ} 48^{\prime} \mathrm{S}\right.$, $\left.52^{\circ} 28^{\prime} \mathrm{W}\right), 80 \mathrm{~km}$ south of the PLE on 18 January 2009, had numerous, small to very large, light grey, verrucous LLD lesions that affected approximately $30 \%$ of its body surface (Fig. 5A). Supported by PI data, its mtDNA control region haplotype matched the most common haplotype found in the Southwestern Atlantic inshore ecotype (Fruet et al. 2014). The dolphin did not belong to the communities residing in the PLE and adjacent coastal waters and was likely a transient.

LLD was not observed in any of the T. truncatus (6 adults and 3 calves) that were repeatedly photographed in the Tramandaí estuary from January 2009 to February 2010. Of the 6 adults, 4 (I6, I7, I9, I11) were known since 1992, 1 (I14) since 2004, and 1 (I15) was first sighted in 2009. Therefore, all adults but 1 had occupied the estuary during a period when LLD occurred there (1999-2005).

During surveys carried out from April 2009 to April 2013, LLD was not detected in T. truncatus (22 adults and 6 calves) photographed in the Mampituba River mouth and adjacent inshore waters. Of the 22 adults, only 1 was known to have used the estuary in 2004 at a time when LLD occurred there (2003-2004). None of the $16 \mathrm{~T}$. truncatus stranded along the coastline 


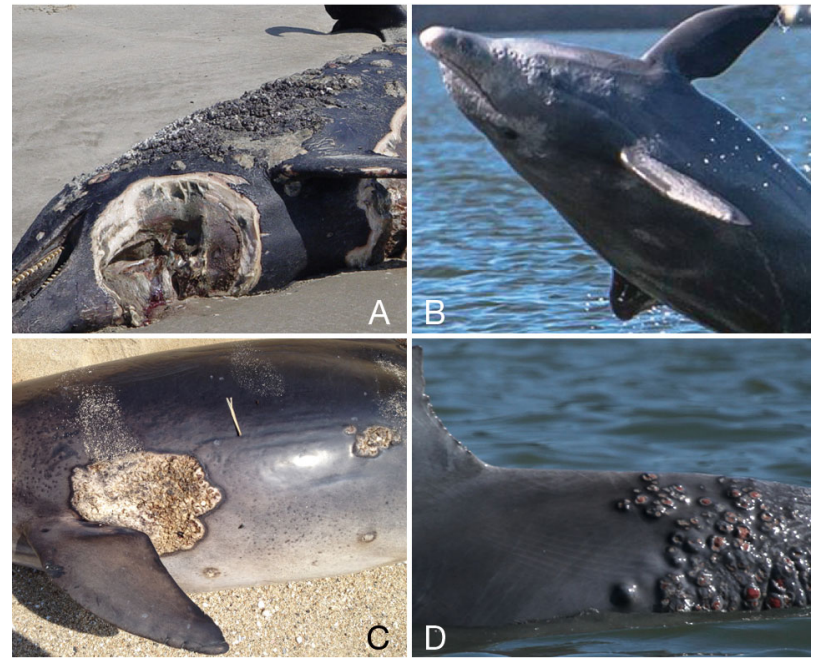

Fig. 5. Lobomycosis-like disease cases in Tursiops truncatus in the Southwest Atlantic, Brazil: (A) mature male stranded dead in Rio Grande do Sul on 15 January 2009; (B) freeranging adult in Laguna on 18 April 2014; (C) adult female stranded dead in Baía Norte, Santa Catarina, on 21 October 2014; and (D) free-ranging dolphin in Sepetiba Bay on 9 September 2013

between Mampituba estuary and the Lagoa do Peixe National Park in 2008 to 2014 had LLD (GEMARS unpubl. data).

\section{Santa Catarina State}

Two of the 4 adult $T$. truncatus (L07, L20) of Laguna confirmed with LLD in 2007 to 2009 were still affected in 2013 to 2014 . The other 2 positive individuals (L17, L19) had disappeared (Daura-Jorge \& Simões-Lopes 2011, unpubl. data). Four other adult dolphins (L04, L34, L38, NI) had developed the disease. On 15 January 2014, L34, which had been photographed regularly since 2010, was recognized with very large LLD lesions on the head, throat, dorsum, trunk and right flipper (Fig. 5B). The dolphin was seen again on 18 April 2014 with no notable changes in LLD lesion size and corporal distribution. On both occasions, it presented an unusual behaviour, namely continuously leaping out of the water and landing on its right side, during the entire observation period (40 min). Conceivably pruritus may be a symptom of LLD, commonly seen in cutaneous mycoses (Francesconi et al. 2014), and could trigger such behaviour. In the other 3 new cases, the disease was characterized by single, small to large, light grey, verrucous lesions. LLD prevalence in adults was $14.3 \%(\mathrm{~N}=42)$ in 2013 to 2014. In 36 adults examined during both periods, the prevalence of LLD was higher in 2013 to
$2014(13.9 \%)$ than in 2007 to 2009 (5.6\%), though not significantly so (McNemar's test, $\chi^{2}=1.42$, df $=35, \mathrm{p}=$ 0.23). During beach surveys carried out in 2012, 16 T. truncatus carcasses were recovered, including 7 from Laguna and 9 of mixed origin (Table 2). All were negative for LLD.

On 21 October 2014, an inshore (confirmed from cranial morphology), sexually mature female $T$. truncatus (UFSC-1420) of unknown residence pattern was found dead in Baía Norte, ca. $90 \mathrm{~km}$ north of Laguna. It had many elevated, small to very large verrucous lesions on the left flank, ventrum and tailstock (Fig. 5C). Some lesions were ulcerated and necrotized. Samples were taken for histology and molecular studies (C. Sacristan \& J. L. Catão Dias pers. comm.).

\section{Rio de Janeiro State}

On 9 September 2013, an adult-sized T. truncatus was photographed with extensive, nodular, ulcerated LLD lesions on its posterior flanks and tailstock (Fig. 5D) in a mangrove area at the centre of Sepetiba Bay. Several nodules were associated with toothrakes. The solitary animal moved back and forth within a restricted area (about $0.02 \mathrm{~km}^{2}$ ) of shallow water less than $6 \mathrm{~m}$ deep, during $7 \mathrm{~d}$, after which it disappeared. At no point was it seen close to Sotalia guianensis groups. It was thought not to belong to the inshore $T$. truncatus community inhabiting waters around Rio de Janeiro (Lodi et al. 2014) but may represent a transient inshore individual. Although the resident community of $S$. guianensis is affected by various skin diseases (Van Bressem et al. 2007, 2015), LLD lesions have never been seen in these dolphins (L. Flach pers. obs.).

\section{Variation in LLD prevalence among study areas}

Among the inshore/estuarine dolphins, prevalence varied significantly (Kruskal-Wallis test, $\chi^{2}=8.65$, $\mathrm{df}=3, \mathrm{p}=0.0343$ ) among 4 communities with the highest prevalence level observed in Salinas (mean \pm SD: $0.17 \pm 0.38)$, followed by Laguna $(0.14 \pm 0.35)$, Mayotte (0.06 \pm 0.24$)$ and Posorja (0.02 \pm 0.15 ; Fig. 6)

\section{DISCUSSION}

This paper provides an update on the epidemiology and geographical distribution of LLD in bottle- 


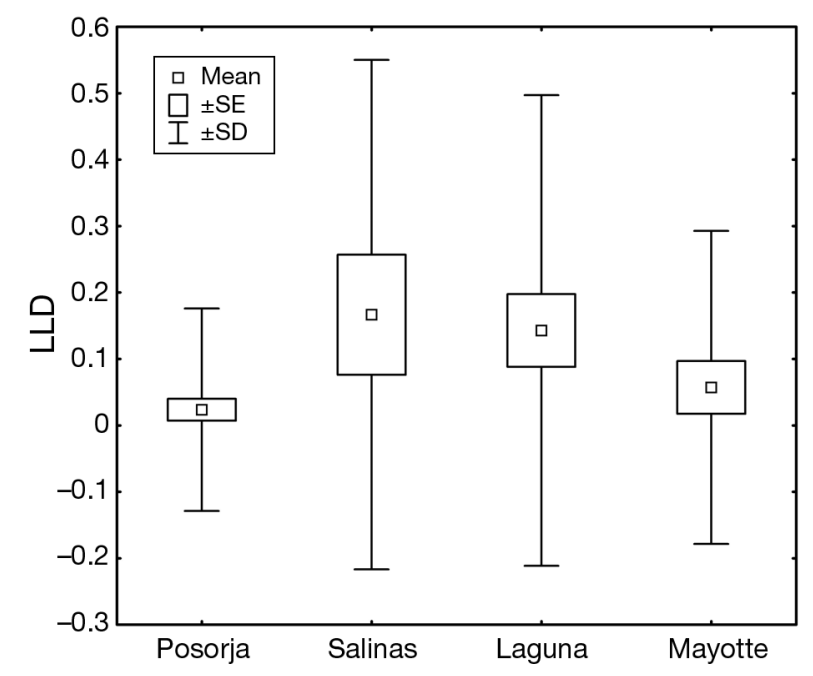

Fig. 6. Variation in lobomycosis-like disease (LLD) prevalence between bottlenose dolphins from South America and southern Africa

nose dolphins from South America and southern Africa in 2004 to 2015. Beach combing and examination of photographs taken during dedicated and opportunistic PI surveys resulted in the identification of 21 cases of LLD in Mayotte, South Africa, Brazil, Ecuador and Colombia (Fig. 1). Macroscopic characteristics of LLD varied between individuals, possibly reflecting disease progression and individual immunologic response, ranging from small to very large, whitish to dark grey, isolated or confluent nodules to plaque-like verrucous lesions that were often ulcerated (Figs. 2, 3 \& 5). This agrees with observations in other Delphinidae populations around the world (Rotstein et al. 2009, Van Bressem et al. 2009a,b, Murdoch et al. 2010, Esperón et al. 2012). However, it is possible that different aetiological agents cause skin diseases resembling lobomycosis in dolphins (Tajima et al. 2015), and further research is necessary. In the Southern Hemisphere, only 3 histological studies have demonstrated the presence of a fungus resembling Lacazia loboi in skin lesions sampled in 2 Tursiops truncatus from Laguna (Simões-Lopes et al. 1993) and the Tramandaí Estuary (Moreno et al. 2008) and a third in a Sousa plumbea from South Africa (Lane et al. 2014). Molecular analysis of the pathogenic agents causing LLD in dolphins from South America and southern Africa will be necessary to firmly establish their taxonomic identity, specifically their relationship to known species of the genus Paracoccidioides and its sister taxon L. loboi.

LLD progression could be assessed in 3 dolphins that were repeatedly sighted in Salinas, Posorja and Mayotte (Figs. 3 \& 4). Although only limited data were available, it appears that progression rate varied between lesions in the same individual (S4) and between individuals, as observed in $T$. truncatus from Sarasota Bay, Florida (Burdett Hart et al. 2010). Very large lesions were observed in a $T$. aduncus from Mayotte that had been infected for at least $6 \mathrm{yr}$ (2008-2014), in 2 free-ranging $T$. truncatus from Sepetiba Bay and Laguna and in 2 stranded dolphins from Baía Norte and Cassino Beach. Present and published data indicate that LLD has persisted for several years in the bottlenose dolphin communities of Mayotte (1999-2014), Laguna (1993-2014), Salinas (2006-2014), Sanquianga National Park (20102013) and Bahía Málaga (2005-2008) (Van Bressem et al. 2007, Kiszka et al. 2009, Daura-Jorge \& SimõesLopes 2011, Herrera et al. 2013). The disease persists because the affected dolphins failed to clear it and also because new individuals became infected. However, our data also show that LLD may vanish from very small $T$. truncatus communities after the death or disappearance of affected individuals and absence of new infections. Five of 6 adults from the Tramandaí Estuary and 1 from Mampituba River did not contract LLD although they were photo-identified in 1999 to 2005 when the disease occurred in these communities (Van Bressem et al. 2007, Moreno et al. 2008). LLD persistence has been observed in T. truncatus in the Indian River Lagoon and Sarasota Bay, Florida, and in Golfo Dulce, Costa Rica (Murdoch et al. 2008, Burdett Hart et al. 2011, Bessesen et al. 2014).

Of the 21 LLD-infected bottlenose dolphins, 17 were inshore residents inhabiting spatially restricted areas that were biologically and chemically contaminated (see 'Materials and methods') and were constantly exposed to multiple anthropogenic stressors, including fisheries. Such factors may depress the immune system and affect skin integrity (Fair \& Becker 2000, Romano et al. 2004, Reif et al. 2009, Martin et al. 2010). Immune compromise was suggested to increase lobomycosis infection risk in $T$. truncatus in the Indian River Lagoon (Reif et al. 2009, Murdoch et al. 2010). A similar situation may occur in resident bottlenose dolphins from South America and Mayotte. Further studies are needed to investigate this hypothesis.

Prevalence varied significantly between resident dolphin communities, being low in Posorja $(2.35 \%)$ and high in Laguna $(14.3 \%)$ and Salinas $(16.7 \%$, Fig. 6). Similarly, LLD prevalence levels in other dolphin communities worldwide varied widely (Table 1). Although differences in sample size and methodology may explain some of this variation, environmental and individual factors likely also play an impor- 
tant role. Burdett Hart et al. (2011) suggested that differences in freshwater input could influence the development and persistence of lobomycosis between $T$. truncatus communities of west and east coast estuaries in Florida. Although several of the areas studied here (Laguna, the mangrove area of Sepetiba Bay, Posorja, Sanquianga National Park and Bahía Malaga) received important riverine freshwater input, this was not the case for Salinas where the highest LLD prevalence was observed. Wilson et al. (1999) reported that bottlenose dolphin communities from areas of low water temperature and low salinity exhibited higher lesion prevalence. In the present study, high LLD prevalence levels were found in areas of medium (Laguna) and high (Mayotte and Salinas) salinity, and both in warm $\left(28.5^{\circ} \mathrm{C}\right.$, Mayotte) and temperate waters $\left(20^{\circ} \mathrm{C}\right.$, Laguna; Table 2). Thus, the role of these factors in the ecology of the disease remains unclear. Low genetic variability could contribute to high LLD prevalence levels in some small communities by altering the immune response (Frank 2002, Sommer 2005). Recent studies showed that among south-western Atlantic $T$. truncatus, the lowest genetic variability was found in the Laguna community where inbreeding is likely to occur, and in a chronically LLD-infected dolphin from the Tramandaí Estuary that died in 2005 (Moreno et al. 2008, Fruet et al. 2014, Costa et al. 2015). In humans, there is mounting evidence that a genetic component may predispose individuals to superficial fungal infections through alterations of the innate and adaptive immune system (Gupta et al. 2014).

LLD seems to have expanded geographically in at least 3 countries where PI surveys and/or beach combing were regularly carried out. In Brazil, LLD was previously determined to be distributed between the Paranaguá Estuary $\left(25^{\circ} 22^{\prime} \mathrm{S}, 48^{\circ} 25^{\prime} \mathrm{W}\right)$ and the Tramandaí Estuary in Sotalia guianensis and T. truncatus (Simões-Lopes et al. 1993, Van Bressem et al. 2007, 2009a, Moreno et al. 2008, Siciliano et al. 2008, Daura-Jorge \& Simões-Lopes 2011). New LLD records in T. truncatus from Sepetiba Bay and Cassino Beach, areas that have been extensively surveyed since the late 1970s (Cassino) and 2005 (Sepetiba), expand the known distribution of the disease $520 \mathrm{~km}$ to the north $\left(22^{\circ} 55^{\prime} \mathrm{S}, 43^{\circ} 53^{\prime} \mathrm{W}\right)$ and ca. $390 \mathrm{~km}$ to the south $\left(32^{\circ} 48^{\prime} \mathrm{S}, 52^{\circ} 28^{\prime} \mathrm{W}\right)$. The Sepetiba and Cassino individuals were transient inshore dolphins, suggesting that these communities may play a role in the geographic expansion of LLD. Interestingly, in South America, the first $T$. truncatus reported with lobomycosis in 1990 was a transient specimen (Simões-Lopes et al. 1993, Simões-Lopes \& Fabian
1999). In Ecuador, LLD was recently (2011-2013) observed in $2 \mathrm{~T}$. truncatus from a community in Posorja of around 100 individuals that was regularly monitored since 2005. LLD was initially described from the inner estuary of the Gulf of Guayaquil $\left(02^{\circ} 52^{\prime} \mathrm{S}, 80^{\circ} 01^{\prime} \mathrm{W}\right)$ with a prevalence of $1.6 \%$ for 441 dolphins in 1990 to 1991 (Van Bressem et al. 2007). The Posorja record expands the known geographical range of the disease to include the outer estuary, some $40 \mathrm{~km}$ to the west. In South Africa, although images of regular quality were available since 2006 and opportunistic surveys were carried out since 1999, LLD was detected only in $1 \mathrm{~T}$. aduncus in November 2008. A case of lobomycosis was documented in 1 of 5 S. plumbea by-caught along the coast of KwaZulu-Natal (about $1000 \mathrm{~km}$ east of Plettenberg Bay) in 2010 to 2011 but not in 35 T. aduncus accidentally captured in the same region during the same period (Lane et al. 2014).

In Laguna, LLD prevalence in 36 adult dolphins more than doubled (albeit without statistical significance) between 2007 and 2009 (5.6\%) and 2014 $(13.9 \%)$. This apparent increase may either reflect natural fluctuations, or may indicate that the disease is spreading in this small, declining community, raising concern for its long-term survival. Although bottlenose dolphins may live with LLD for years, severely affected individuals have died or disappeared in the Americas and southern Africa, including 2 adult Laguna residents sighted in 2007 to 2009 but not in 2014 (Moreno et al. 2008, Bermúdez et al. 2009, Kiszka et al. 2009, Daura-Jorge \& SimõesLopes 2011). Among the 21 dolphins observed with LLD during this study, 2 were found dead with extensive skin lesions in Brazil and 2 others disappeared and presumably died in Ecuador, a presumed 19\% mortality rate. The persistence, high prevalence levels and unknown case fatality rates of LLD in some small, and sometimes endangered, communities of $T$. truncatus and $T$. aduncus are a cause for concern. These data stress the need for intensified, targeted epidemiological, histological and molecular studies of this disease in Delphinidae in the Southern Hemisphere.

Acknowledgements. We thank 3 anonymous reviewers for their constructive comments on the manuscript. We thank Lina Correa for help with data collection in Bahía Málaga and surroundings; and Johana Velasquez, Colombo Estupiñán, Paula Casas and Saturnino Montaño for their support. Rodrigo Genoves and Rafael Camargo are kindly acknowledged for collecting the $T$. truncatus stranded south of the Patos Lagoon Estuary. We thank researchers from GEMARS and the support from CECLIMAR/UFRGS for collecting the stranded common bottlenose dolphin from the 
northern coast of Rio Grande do Sul and Silvina Botta for age determination of the dolphin from Cassino Beach, Brazil. We thank J. Brack and R. Amboni for providing Figs. 2B and 5B, respectively. A fellowship and financial support was granted by the Conselho Nacional de Desenvolvimento Científico e Tecnológico (CNPq) to E.R.S. (PQ 307846/2014-8) and P.H.O. (Process 572180/2008-0), who contributed as members of the Research Group 'Ecologia e Conservação da Megafauna Marinha - EcoMega/CNPq' and 'Ecologia e Conservação de Organismos e Ambientes Aquáticos - ECOAqua/ CNPq'. L.F. was sponsored by Petrobras through Petrobras Socio Ambiental. We thank T. Gridley, V. Cockcroft and M. N. Bester for assistance with the South African data access and analysis, as well as the Centre for Dolphin Studies and Orca Foundation. Data collection around Mayotte was supported by 'Collectivité Départementale de Mayotte, Ministère de l'Environment, Agence des Aires Marines Protégées' and the 'Fond National de la Recherche du Luxembourg'.

\section{LITERATURE CITED}

Andrade VM, Silva J, Silva FR, Heuser VD, Dias JF, Yoneama ML, Freitas TRO (2004) Fish as bioindicators to assess the effects of pollution in two southern Brazilian rivers using the comet assay and micronucleus test. Environ Mol Mutagen 44:459-468

> Bagagli E, Franco M, Bosco SDM, Hebeler-Barbosa F, Trinca LA, Montenegro MR (2003) High frequency of Paracoccidioides brasiliensis infection in armadillo (Dasypus novemcinctus): an ecological study. Med Mycol 41:217-223

Bermúdez L, Van Bressem MF, Reyes-Jaimes O, Sayegh AJ, Paniz-Mondolfi AE (2009) Lobomycosis in man and lobomycosis-like disease in bottlenose dolphin, Venezuela. Emerg Infect Dis 15:1301-1303

> Bessesen BL, Oviedo L, Burdett Hart L, Herra-Miranda D and others (2014) Lacaziosis-like disease among bottlenose dolphins Tursiops truncatus photographed in Golfo Dulce, Costa Rica. Dis Aquat Org 107:173-180

Bocca AL, Amaral AC, Teixeira MM, Sato PK, ShikanaiYasuda MA, Soares Felipe MS (2013) Paracoccidioidomycosis: eco-epidemiology, taxonomy and clinical and therapeutic issues. Future Microbiol 8:1177-1191

Bossart GD (1984) Suspected acquired immunodeficiency in an Atlantic bottlenosed dolphin with chronic-active hepatitis and lobomycosis. J Am Vet Med Assoc 185: 1413-1414

Burdett Hart L, Wells RS, Adams JD, Rotstein DS, Schwacke LH (2010) Modeling lacaziosis lesion progression in common bottlenose dolphins Tursiops truncatus using longterm photographic records. Dis Aquat Org 90:105-112

Burdett Hart L, Rotstein DS, Wells RS, Bassos-Hull K, Schwacke LH (2011) Lacaziosis and lacaziosis-like prevalence among wild, common bottlenose dolphins Tursiops truncatus from the west coast of Florida, USA. Dis Aquat Org 95:49-56

Caldwell DK, Caldwell MC, Woodard JC, Ajello L, Kaplan W, McLure HM (1975) Lobomycosis as a disease of the Atlantic bottle-nosed dolphin (Tursiops truncatus Montagu, 1821). Am J Trop Med Hyg 24:105-114

> Copeland G, Monteiro T, Couch S, Borthwick A (2003) Water quality in Sepetiba Bay, Brazil. Mar Environ Res 55:385-408

> Corredor GG, Peralta LA, Castaño JH, Zuluaga JS and others (2005) The naked-tailed armadillo Cabassous centralis (Miller 1899): a new host to Paracoccidioides brasiliensis. Molecular identification of the isolate. Med Mycol 43:275-280

Costa APB, Fruet P, Daura-Jorge FG, Simões-Lopes PC, Ott $\mathrm{PH}$, Valiati VH, Oliveira LR (2015) Bottlenose dolphin communities from the southern Brazilian coast: Do they exchange genes or are they just neighbours? Mar Freshw Res (in press) http://dx.doi.org/10.1071/MF14007

- Cowan DF (1993) Lobo's disease in a bottlenose dolphin (Tursiops truncatus) from Matagorda Bay, Texas. J Wildl Dis 29:488-489

CPPS (Comisión permanente del Pacifico Sur) (2014) Estado del Medio Ambiente Marino y Costero del Pacífico Sudeste. Serie Estudios Regionales 4. CPPS, Guayaquil

> D'Aquino CA, Neto JSA, Barreto GAM, Schettini CAF (2011) Caracterização oceanográfica e do transporte de sedimentos em suspensão no estuário do rio Mampituba, SC. Rev Bras Geofís 29:217-230

> Daura-Jorge FG, Simões-Lopes PC (2011) Lobomycosis-like disease in wild bottlenose dolphins Tursiops truncatus of Laguna, southern Brazil: monitoring of a progressive case. Dis Aquat Org 93:163-170

> Daura-Jorge F, Ingram S, Simões-Lopes PC (2013) Seasonal abundance and adult survival of bottlenose dolphins (Tursiops truncatus) in a community that cooperatively forages with fishermen in southern Brazil. Mar Mamm Sci 29:293-311

de Vries GA, Laarman JJ (1973) A case of Lobo's disease in the dolphin Sotalia guianensis. Aquat Mamm 1:26-33

Di Giacomo AB (2014) Padrão de ocorrência e uso de habitat do golfinho-nariz-de-garrafa (Tursiops truncatus) no estuário do rio Mampituba e regiões adjacentes, no sul do Brasil. MSc thesis, Universidade Federal do Espírito Santo, Aracruz

Di Giacomo AB, Ott PH (in press) Long-term site fidelity and residency patterns of bottlenose dolphins (Tursiops truncatus) in the Tramandaí estuary, southern Brazil. Lat Am $\mathrm{J}$ Aquat Mamm

Díaz JM, Acero A (2003) Marine biodiversity in Colombia: achievements, status of knowledge, and challenges. Gayana Zool 67:261-274

du Toit K (2011) Prevalence of skin disease and ectoparasites in bottlenose dolphins around southern Africa. BSc Honours thesis, University of Pretoria

Esperón F, García-Párraga D, Bellière EN, Sánchez-Vizcaíno JM (2012) Molecular diagnosis of lobomycosis-like disease in a bottlenose dolphin in captivity. Med Mycol 50: 106-109

Fair PA, Becker PR (2000) Review of stress in marine mammals. J Aquat Ecosyst Stress Recovery 7:335-354

Félix F (1994) Ecology of the coastal bottlenose dolphin Tursiops truncatus in the Gulf of Guayaquil, Ecuador. Invest Cetacea 25:235-256

Félix F (1997) Organization and social structure of the bottlenose dolphin Tursiops truncatus in the Gulf of Guayaquil, Ecuador. Aquat Mamm 23:1-16

FEPAM (Fundação Estadual de Proteção Ambiental Henrique Luiz Roessler) (2015) Monitoramento da qualidade da água da Região Hidrográfica das Bacias Litorâneas. Available at www.fepam.rs.gov.br/qualidade/ balneabilidade_historico.asp (accessed 20 Feb 2015)

Flach L (2015) Estimativa de parâmetros populacionais, área de vida, mortalidade e impactos da atividade pesqueira sobre a população de botos-cinza (Sotalia guianensis) (Van Bénéden, 1864) (Cethartiodactyla, Delphinidae) na 
Baía de Sepetiba (RJ). PhD thesis, Universidade do Estado do Rio de Janeiro

Flach L, Flach PA, Chiarello AG (2008) Aspects of behavioral ecology of Sotalia guianensis in Sepetiba Bay, southeast Brazil. Mar Mamm Sci 24:503-515

Flores PAC, Bazzalo M, Da Silva LZ, Wells RS (2005) Evidência de residência individual e ocorrência de lesões epidérmicas em golfinhos Tursiops truncatus na Baía Norte, SC, Brasil. In: Fagundes V, Costa LP, Leite LR, Mendes SL (eds) Livro de Resumos, III Congresso Brasileiro de Mastozoologia, 12-16 October, 2005, Aracruz, Espirito Santo, p 87

Francesconi VA, Klein AP, Santos AP, Ramasawmy R, Francesconi F (2014) Lobomycosis: epidemiology, clinical presentation, and management options. Ther Clin Risk Manag 10:851-860

Frank SA (2002) Immunology and evolution of infectious disease. Princeton University Press, Princeton, NJ

Fruet PF, Secchi ER, Di Tullio JC, Kinas PG (2011) Abundance of bottlenose dolphins, Tursiops truncatus (Cetacea: Delphinidae), inhabiting the Patos Lagoon estuary, southern Brazil: implications for conservation. Zoologia 28:23-30

Fruet PF, Secchi ER, Daura-Jorge F, Vermeulen E and others (2014) Remarkably low genetic diversity and strong population structure in common bottlenose dolphins (Tursiops truncatus) from coastal waters of the Southwestern Atlantic Ocean. Conserv Genet 15:879-895

> Fruet PF, Daura-Jorge F, Möller LM, Genoves RC, Secchi ER (2015a) Abundance and demography of bottlenose dolphins inhabiting a sub-tropical estuary in the Southwestern Atlantic Ocean. J Mammal 96:332-343

Fruet PF, Genoves RC, Möller LM, Botta S, Secchi ER (2015b) Using mark-recapture and stranding data to estimate reproductive traits in female bottlenose dolphins (Tursiops truncatus) of the Southwestern Atlantic Ocean. Mar Biol 162:661-673

- Garcia MR, Mirlean N, Baisch PR, Caramão EB (2010) Assessment of polycyclic aromatic hydrocarbon influx and sediment contamination in an urbanized estuary. Environ Monit Assess 168:269-276

> Gupta AK, Simpson FC, Brintnell WC (2014) Do genetic mutations and genotypes contribute to onychomycosis? Dermatology 228:207-210

Haase J, Stringuini MH, Silva MLBC, Rodrigues MLK, Koch SMV (2003) Qualidade das águas superficiais do litoralnorte e médio do Rio Grande do Sul. In: $22^{\circ}$ Congresso Brasileiro de Engenharia Sanitária e Ambiental, 14-19 Sep, Joinville, Brazil. Available at www.fepam.rs.gov.br/ qualidade/arg/VI_049-QAS_LN_LM_RS.pdf

Herr RA, Tarcha EJ, Taborda PR, Taylor JW, Ajello L, Mendoza L (2001) Phylogenetic analysis of Lacazia loboi places this previously uncharacterized pathogen within the dimorphic Onygenales. J Clin Microbiol 39:309-314

Herrera JC, Van Bressem MF, Cantera-Kintz JR (2013) Presencia de lobomycosis en delfines nariz de botella (Tursiops truncatus), en aguas cercanas al Parque Nacional Natural Sanquianga. In: Campos NH, Dueñas P (eds) Memorias del XV Seminario Nacional de Ciencias y Tecnologías del Mar, Cartagena, Colombia, p 149-150

Hurtado MD, Hurtado MG, Hurtado L (2012) Estado de la contaminación marina en Ecuador. Consultancy report to the Permanent Commission for the South Pacific (CPPS), Guayaquil, Ecuador. http://cpps.dyndns.info/cpps-docsweb/planaccion/docs2013/mar/xix_ag/025.\%20INFORME _FINAL_ECU_CONTAMINACIÓN_MARINA.pdf
IWC (International Whaling Commission) (2009) Report of the Workshop on Cetacean Skin Diseases. J Cetacean Res Manag 11:503-516

Kiszka J, Van Bressem MF, Pusineri C (2009) Lobomycosislike disease and other skin conditions in Indo-Pacific bottlenose dolphins Tursiops aduncus from the Indian Ocean. Dis Aquat Org 84:151-157

Kiszka J, Simon-Bouhet B, Gastebois C, Pusineri C, Ridoux V (2012) Habitat partitioning and fine scale population structure among insular bottlenose dolphins (Tursiops aduncus) in a tropical lagoon. J Exp Mar Biol Ecol 416417:176-184

Kjerfve B (1986) Comparative oceanography of coastal lagoons. In: Wolfe DA (ed) Estuarine variability. Academic Press, New York, NY, p 63-81.

Lane EP, de Wet M, Thompson P, Siebert U, Wohlsein P, Plön S (2014) A systematic health assessment of Indian ocean bottlenose (Tursiops aduncus) and Indo-Pacific humpback (Sousa plumbea) dolphins incidentally caught in shark nets off the KwaZulu-Natal Coast, South Africa. PLoS ONE 9:e107038

Lélis RJF, Calliari LJ (2006) Historical shoreline changes near lagoonal and river stabilized inlets in Rio Grande do Sul state, southern Brazil. J Coast Res Spec Issue 39: 301-305

Lodi L, Cantor M, Daura-Jorge F, Monteiro-Neto C (2014) A missing piece from a bigger puzzle: declining occurrence of a transient group of bottlenose dolphins off Southeastern Brazil. Mar Ecol 35:516-527

> Mann J, Smuts B (1999) Behavioral development of wild bottlenose dolphin newborns. Behaviour 136:529-566

Mann J, Connor RC, Barre LM, Heithaus MR (2000) Female reproductive success in bottlenose dolphins (Tursiops sp.): life history, habitat, provisioning, and group-size effects. Behav Ecol 11:210-219

> Martin LB, Hopkins WA, Mydlarz LD, Rohr JR (2010) The effects of anthropogenic global changes on immune functions and disease resistance. Ann NY Acad Sci 1195: 129-148

> Migaki G, Valerio MG, Irvine B, Garner FM (1971) Lobo's disease in an Atlantic bottle-nosed dolphin. J Am Vet Med Assoc 159:578-582

> Mirlean N, Andrus VE, Baisch P (2003) Mercury pollution sources in sediments of Patos Lagoon Estuary, Southern Brazil. Mar Pollut Bull 46:331-334

> Molisani MM, Marins RV, Machado W, Paraquetti HHM, Bidone ED, Lacerda LD (2004) Environmental changes in Sepetiba Bay, SE Brazil. Reg Environ Change 4:17-27

Moreno IB, Ott PH, Tavares M, Oliveira LR and others (2008) Mycotic dermatitis in common bottlenose dolphins (Tursiops truncatus) from southern Brazil, with a confirmed record of lobomycosis disease. Paper SC/60/DW1 presented to the IWC Scientific Committee, Santiago, Chile, May 2008

> Murdoch ME, Reif JS, Mazzoil M, McCulloch SD, Fair PA, Bossart GD (2008) Lobomycosis in bottlenose dolphins (Tursiops truncatus) from the Indian River Lagoon, Florida: estimation of prevalence, temporal trends, and spatial distribution. EcoHealth 5:289-297

> Murdoch ME, Mazzoil M, McCulloch S, Bechdel S, O'CorryCrowe G, Bossart GD, Reif JS (2010) Lacaziosis in bottlenose dolphins Tursiops truncatus along the coastal Atlantic Ocean, Florida, USA. Dis Aquat Org 92:69-73

Naranjo LG, Castillo LF, Johnston-González R, Hernández C, Ruiz C, Estela F (2006) Waterbird monitoring and con- 
servation in protected areas of the Colombian Pacific. In: Boere GC, Galbraith CA, Stroud DA (eds) Waterbirds around the world. The Stationery Office, Edinburgh, p $177-180$

Ott PH, Barreto AS, Siciliano S, Laporta P and others (in press) Report of the working group on taxonomy and stock identity of bottlenose dolphins in the Southwestern Atlantic Ocean. Lat Am J Aquat Mamm

Palmer C, Peterson A (2014) First report of a lacaziosis-like disease (LLD) observed in the Australian snubfin dolphin (Orcaella heinsohni) in Darwin Harbour, Northern Territory, Australia. North Territ Nat 25:3-6

> Paniz-Mondolfi A, Talhari C, Sander Hoffman L, Connor DL and others (2012) Lobomycosis: an emerging disease in humans and Delphinidae. Mycoses 55:298-309

Parra AS, Restrepo Á (2014) El colapso ambiental en el río Patía, Colombia: variaciones morfológicas y alteraciones en los ecosistemas de manglar. Lat Am J Aquat Res 42: $40-60$

> Pessanha AL, Araújo FG (2003) Spatial, temporal and diel variations of fish assemblages at two sandy beaches in the Sepetiba Bay, Rio de Janeiro, Brazil. Estuar Coast Shelf Sci 57:817-828

Phillips GL (2006) Bottlenose dolphins (Tursiops aduncus) in Plettenberg Bay, South Africa: population estimates and temporal dynamics of groups. MSc thesis, Nelson Mandela Metropolitan University, Port Elizabeth

> Pinotti RM, Colling L, Bemvenuti CE (2011) Temporal dynamics of deep infralittoral macrobenthic fauna inside a subtropical estuarine environment. Braz J Aquat Sci Technol 15:26-41

PNN (Parque Nacional Natural) Sanquianga (2013) Actualización del Plan de Manejo del Parque Nacional Natural Sanquianga Componente Diagnóstico. Ministerio de ambiente y desarrollo sostenible parques nacionales, Dirección Territorial Pacifico, Cali, Columbia

PNN Uramba Bahía Málaga (2014) Componente ordenamiento para el Plan de Manejo Parque Nacional Natural Uramba Bahía Málaga. Dirección Territorial Pacífico, Parques Nacionales Naturales de Colombia, Bahía Málaga, Buenaventura, Valle del Cauca - Pacífico Colombiano

Pusineri C, Barbraud C, Kiszka J, Caceres S, Mougnot J, Daudin G, Ridoux V (2014) Capture-mark-recapture modelling suggests an Endangered status for the Mayotte Island (eastern Africa) population of Indo-Pacific bottlenose dolphins. Endang Species Res 23:23-33

Quod JP, Naim O, Abdourazi F (2000) The Comoros archipelago. In: Sheppard C (ed) Seas at the Millennium: an environmental evaluation. Pergamon Press, Oxford, p 243-252

Reif JS, Mazzoil MS, McCulloch SD, Varela RA, Goldstein JD, Fair PA, Bossart GD (2006) Lobomycosis in Atlantic bottlenose dolphins from the Indian River Lagoon, Florida. J Am Vet Med Assoc 228:104-108

Reif JS, Peden-Adams MM, Romano TA, Rice CD, Fair PA, Bossart GD (2009) Immune dysfunction in Atlantic bottlenose dolphins (Tursiops truncatus) with lobomycosis. Med Mycol 47:125-135

Reisinger RR, Karczmarski L (2010) Population size estimate of Indo-Pacific bottlenose dolphins in the Algoa Bay region, South Africa. Mar Mamm Sci 26:86-97

Rengifo B, Capella J, Flórez González L (1995) Patterns of occurrence of bottlenose dolphins in Bahía Málaga, Colombian Pacific: preliminary observations. In: 11th Biennial Conference on the Biology of Marine Mammals,
Orlando, FL. Society for Marine Mammalogy, Moss Landing, CA, p 96

Ribeiro AP, Figueiredo AM, dos Santos JO, Dantas E and others (2013) Combined SEM/AVS and attenuation of concentration models for the assessment of bioavailability and mobility of metals in sediments of Sepetiba Bay (SE Brazil). Mar Pollut Bull 68:55-63

- Ricci G, Mota FT, Wakamatsu A, Serafim RC, Borra RC, Franco M (2004) Canine paracoccidioidomycosis. Med Mycol 42:379-383

Richini-Pereira VB, Bosco SDMG, Griese J, Theodoro RC and others (2008) Molecular detection of Paracoccidioides brasiliensis in road-killed wild-animals. Med Mycol 46:35-40

Rocha CM (2013) Qualidade das águas na BH Rio Tramandaí. In: Castro D, Mello RSP (eds) Atlas ambiental da bacia hidrográfica do Rio Tramandaí. Edicions Via Sapiens, Porto Alegre, p 149-155

> Romano TA, Keogh MJ, Kelly C, Feng P and others (2004) Anthropogenic sound and marine mammal health: measures of the nervous and immune systems before and after intense sound exposure. Can J Fish Aquat Sci 61: 1124-1134

Rotstein DS, Burdett-Hart LG, McLellan W, Schwacke L and others (2009) Lobomycosis in offshore bottlenose dolphins (Tursiops truncatus), North Carolina. Emerg Infect Dis 15:588-590

Schwarzbold A. Schäfer A (1984) Gênese e morfologia das lagoascosteiras do Rio Grande do Sul, Brasil. Amazoniana 9:87-104

Siciliano S, Van Bressem MF, Moreno IB, Ott PH and others (2008) Review of lobomycosis and lobomycosis-like disease (LLD) in Cetacea from South America. Paper SC/60/DW13 presented to the IWC Scientific Committee, Santiago, Chile, May 2008. www.researchgate.net/publication/272 018662_Review_of_Lobomycosis_and_Lobomycosis-like_ disease_\%28LLD\%29_in_Cetacea_from_South_America

Simões-Lopes PC, Fabian ME (1999) Residence patterns and site fidelity in bottlenose dolphins, Tursiops truncatus (Montagu) (Cetacea, Delphinidae) off Southern Brazil. Rev Bras Zool 16:1017-1024

Simões-Lopes PC, Paula GS, Xavier FM, Scaramelo AC (1993) First case of lobomycosis in a bottlenose dolphin from southern Brazil. Mar Mamm Sci 9:329-331

> Sommer S (2005) The importance of immune gene variability (MHC) in evolutionary ecology and conservation. Front Zool 2:16

> Souza DSM, Ramos APD, Nunes FF, Moresco V and others (2012) Evaluation of tropical water sources and mollusks in southern Brazil using microbiological, biochemical and chemical parameters. Ecotoxicol Environ Saf 76:153-161

Symmers WS (1983) A possible case of Lobo's disease acquired in Europe from a bottlenosed-dolphin (Tursiops truncatus). Bull Soc Pathol Exot Filiales 76:777-784

Taborda PR, Taborda VA, McGinnins MR (1999) Lacazia loboi gen. nov., comb. nov., the etiologic agent of lobomycosis. J Clin Microbiol 37:2031-2033

> Tajima Y, Sasaki K, Kashiwagi N, Yamada TK (2015) A case of stranded Indo-Pacific bottlenose dolphin (Tursiops aduncus) with lobomycosis-like skin lesions in Kinkowan, Kagoshima, Japan. J Vet Med Sci 77:989-992

Theodoro RC, Teixeira MDM, Felipe MS, Paduan KDS, Ribolla PM, San-Blas G, Bagagli E (2012) Genus Paracoccidioides: species recognition and biogeographic aspects. PLoS ONE 7:e37694 
Thomassin BA, Garcia F, Lagadec V, Sarrazin L and others (2008) Mayotte: évaluation de la qualité des eaux côtières du lagon à partir des polluants dosés dans les huîtres médiolittorales (Octobre-Novembre 2007). Report of GIS LagMay, Direction de l'Agriculture et de la Forét de Mayotte, Momoudzou

Torres JI, Pinzón MP, Esquivia M, Parra A, Espitia E (2012) La explotación ilícita de recursos minerales en Colombia: Casos Valle del Cauca (Río Dagua)-Chocó (Río San Juan), Efectos sociales y ambientales. Contraloría Delegada, Sector Minas y Energía, Contraloría General de la República, Bogotá

Ueda K, Sano A, Yamate J, Itano Nakagawa E and others (2013) Two cases of lacaziosis in bottlenose dolphins (Tursiops truncatus) in Japan. Case Rep Vet Med 2013:318548

Van Bressem MF, Van Waerebeek K, Reyes JC, Felix F and others (2007) A preliminary overview of skin and skeletal diseases and traumata in small cetaceans from South American waters. Lat Am J Aquat Mamm 6:7-42

> Van Bressem MF, de Oliveira Santos MC, de Faria Oshima JE (2009a) Skin diseases in Guiana dolphins (Sotalia guianensis) from Paranagua estuary, Brazil: a possible

Editorial responsibility: Michael Moore, Woods Hole, Massachusetts, USA indicator of a compromised marine environment. Mar Environ Res 67:63-68

- Van Bressem MF, Raga JA, Di Guardo G, Jepson PD and others (2009b) Emerging infectious diseases in cetaceans worldwide and the possible role of environmental stressors. Dis Aquat Org 86:143-157

- Van Bressem MF, Flach L, Reyes JC, Echegaray M and others (2015) Epidemiological characteristics of skin disorders in cetaceans from South American waters. Lat Am J Aquat Mamm 10:20-32

Wilson B, Arnold H, Berazi G, Fortuna CM and others (1999) Epidermal lesions in bottlenose dolphins: impacts of natural and anthropogenic factors. Proc R Soc Lond B Biol Sci 266:1077-1083

Würsig B, Jefferson RA (1990) Methods of photo-identification for small cetaceans. Rep Int Whal Comm Spec Issue $12: 42-43$

Zappes CA, Andriolo A, Simões-Lopes PC, Di Beneditto APM (2011) 'Human-dolphin (Tursiops truncatusMontagu, 1821) cooperative fishery' and its influence on cast net fishing activities in Barra de Imbé/Tramandaí, Southern Brazil. Ocean Coast Manag 54:427-432

Submitted: March 23, 2015; Accepted: September 21, 2015 Proofs received from author(s): October 30, 2015 